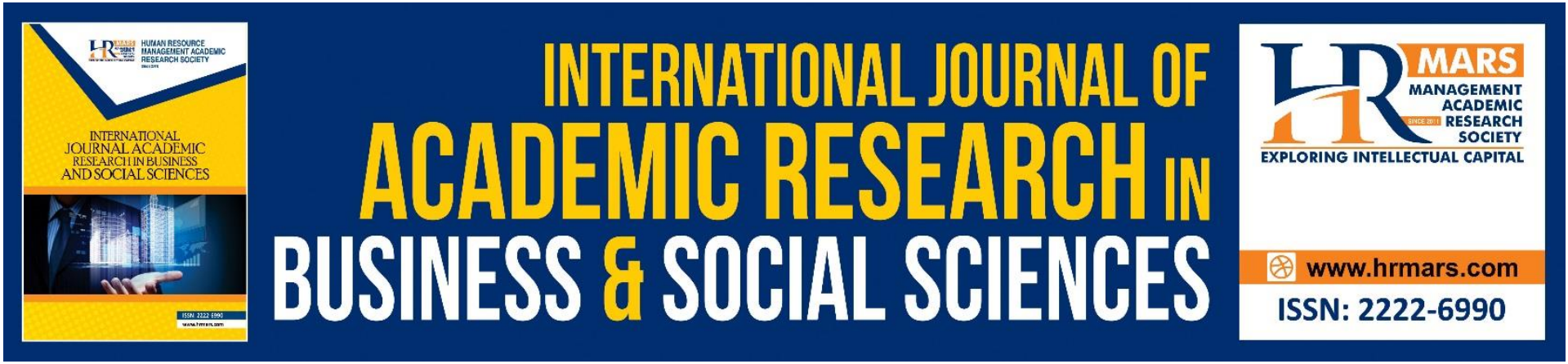

\title{
Contrastive Analysis on French and Malay Language Prepositions
}

Shobehah Abdul Karim, Vijayaletchumy Subramaniam

To Link this Article: http://dx.doi.org/10.6007/IJARBSS/v11-i12/11944 ～DOI:10.6007/IJARBSS/v11-i12/11944

Received: 08 October 2021, Revised: 10 November 2021, Accepted: 25 November 2021

Published Online: 15 December 2021

In-Text Citation: (Karim \& Subramaniam, 2021)

To Cite this Article: Karim, S. A., \& Subramaniam, V. (2021). Contrastive Analysis on French and Malay Language Prepositions. International Journal of Academic Research in Business and Social Sciences, 11(12), $2235-2246$.

Copyright: @ 2021 The Author(s)

Published by Human Resource Management Academic Research Society (www.hrmars.com)

This article is published under the Creative Commons Attribution (CC BY 4.0) license. Anyone may reproduce, distribute, translate and create derivative works of this article (for both commercial and non0-commercial purposes), subject to full attribution to the original publication and authors. The full terms of this license may be seen at: http://creativecommons.org/licences/by/4.0/legalcode

Vol. 11, No. 12, 2021, Pg. 2235- 2246

http://hrmars.com/index.php/pages/detail/IJARBSS

Full Terms \& Conditions of access and use can be found at http://hrmars.com/index.php/pages/detail/publication-ethics 


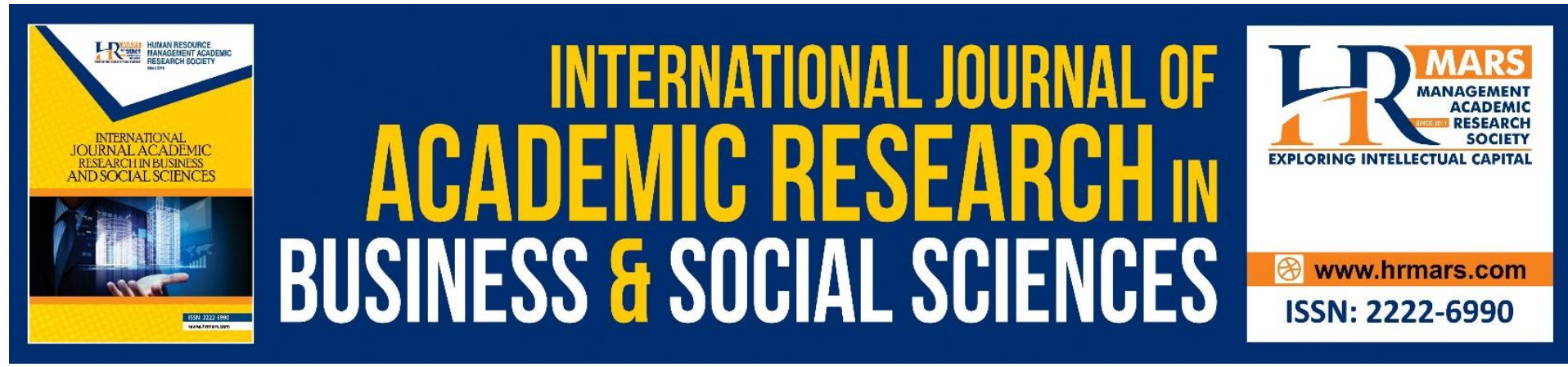

\title{
Contrastive Analysis on French and Malay Language Prepositions
}

\author{
Shobehah Abdul Karim¹, Vijayaletchumy Subramaniam²
}

${ }^{1}$ Universiti Kuala Lumpur Malaysia France Institute,43650 Bandar Baru Bangi, Selangor, Malaysia, ${ }^{2}$ Universiti Putra Malaysia, Department of Malay Language, Faculty of Modern

Languages and Communication 43400 UPM Serdang, Selangor, Malaysia

\begin{abstract}
The learning of French as a foreign language (FL) demands the student to master writing and speaking skills well. The mastery of basic French grammar is highly helpful to develop these skills. This research is limited to the comparison of French preceding preposition of location for "di" with Malay Language (BM) in writing simple French sentences. Research methodology is conducted by document analysis research. Research respondents comprises of 50 French 1 (WFD10101) students from University Kuala Lumpur Malaysia France Institute (UniKL MFI). The research locale is UniKL MFI. The research findings are analysed descriptively. The researcher uses Lado's Contrastive Analysis Theory (1957) to discern the similarities and differences between the preceding preposition of location for "di" in French and BM. The research instruments are the essays from the French 1 tests and questionnaires. The research findings showed that the comprehension on the similarities and differences of French and BM helped respondents in writing simple French sentences. The similarities aided the respondents in building sentences, while the differences confused the respondents when choosing the correct preposition. There are various different French prepositions for " $\mathrm{di}$ " if the place stated is a country. There are three prepositions for country in French, namely "en", "au", or "aux" which are differentiated by the gender factor whether the country is feminine, masculine, or in plural form. Meanwhile the French equivalent of the preposition "di" is the preposition "à". This preposition is written before the proper noun of a place such as cities, villages, and islands. The respondents performed errors when choosing prepositions due to the range of French prepositions. In summary, this comparison research hopes to benefit educators and students alike for French as a FL in Malaysia.
\end{abstract}

Keywords: Preposition, Country, CA, Malay, French.

\section{Introduction}

Learning of French as a foreign language is fast picking up pace in Malaysia and is now taught in boarding schools, selected daily schools, as well as in higher education institutions. The distance between the original country of the target language (TL), France, that is far from Malaysia has created a limitation in the communication skills. These days, the struggle to obtain reference materials can be overcome by online searches or additional notes uploaded into online learning portals. The advent of technology has made learning environments no 
longer a valid reason for respondents to not be able to master the basic skills of writing French. In the early stages of learning French as a FL, the respondents would first and foremost be taught how to build simple French sentences by using sentence structures and correct French grammar such as using the preposition of location "di" in French. Despite the tutoring as well as in-class at at-home practices, the respondents still made mistakes in French prepositions "en", "au", "aux" and "à", or the BM preposition of location "di". These mistakes in choosing French preposition of location among the respondents are influenced by several factors and in turn affect their marks for their written tests. With that, the mistakes made with the "en", "au", "aux" and "à" prepositions have created a void for researchers to conduct a study to compare French-BM prepositions, especially in identifying the similarities and differences between the French prepositions of location "en", "au", "aux", "à" with the BM

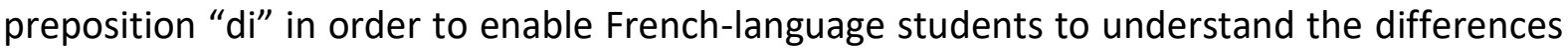
when using every French preposition by taking into account the gender name for the country, city or place and in turn aiding the students to choose the correct prepositions when writing in French.

\section{Literature Review}

A development in learning FL has pushed researchers such as Che Su (2017); Baihaqi \& Aminallah (2017); Nur (2016); Nor et al (2015); Hassan \& Mohamad (2014) to perform Contrastive Analysis (CA) research on BM and FL learning. Che Su (2017) performed CA research on the Thai language, Baihaqi \& Aminallah (2017); Nur (2016) researched Arabic language CA, Mohd Nor et al (2015) for Spanish, and Hassan \& Mohamad (2014) conducted CA research on the French language. However, Al-khresheh (2016); Zaki (2015) shifted their research focus more on the CA Theory and the implications of CA theory towards learning a FL. Al-khresheh (2016) literature review supports the researcher's selection of the research theory as his own findings on the CA Theory is still significant and relevant to this day. Similarly, the literature review by Zaki (2015) also clarified the benefits of CA when comparing B1 and B2. Other than that, this literature review also provides a picture to researchers on the methods to perform comparative study of the FL with BM through CA. According to the study by Al-khresheh (2016), although there are several highly debated issues discussed on $C A$, it appears that CA has been given a new breath of life by language researchers. Researchers have also agreed that the field of CA is still wide and has many avenues to be pioneered and explored. In line with this, this literature review also provides an impact to researchers conducting CA studies based on Lado's Theory of Contrastive Analysis (1957). This theory was also the choice of past studies such as by Che Su (2017); Nur (2016) \& Nor et al (2015). A review by Zaki (2015) also stated the contribution of CA in Teaching and Learning (T\&L) in the ability to predict and diagnose mistakes by B2 students as well as to design a test as a guide for B1 students. Therefore, this literature review also shapes an idea to researchers to choose Lado's Theory of Contrastive Analysis (1957) when conducting analytical research of French-BM essays writing.

As a whole, the above research are more focused on CA for the Arab, Thai, Spanish, and English languages as a FL except for (Hassan \& Mohamad, 2014). They chose to conduct research on French-BM CA. Hassan \& Mohamad (2014) compared the usage of supporting verbs in BM as was found in the usage of French "verbe support". Their research was based on the Lexicon-Grammar (Lexique-Grammaire) theory, which is based on Harris principle (1964), which was then developed by Gross $(1975 ; 1981)$. Therefore, these studies have given 
an idea to researchers to conduct FL research on French-BM by identifying the similarities and differences of French CA "en", "au", "aux", "à" to match with the verb "HABITER" which means "to live" with the BM preceding proposition for "di". Meanwhile, Zaki (2015) stated in their study that CA and the error analysis for both, too, play a role in analysing mistakes made by the students. Contrastive analysis and error analysis complement one another. James (1980) claimed that CA helped students if there was an error when learning language and if the observed mistake was caused by the transferring of B1 or an influence from other languages. James also supported that during the process of learning language, when there is interference such as "interlanguage", it may cause something simple to become difficult, and that this problem may be overcome by the CA approach. Starting from this literature review, researchers had the idea to conduct CA studies and would then choose the approach by Zaki (2015) in conducting comparative research on the preposition of location for French-BM. The findings from the Error Analysis research help discern the mistakes in choosing prepositions, and from there the data was used to study the similarities and differences found in the preposition of location "di" for French-BM.

\section{Research Objectives}

This research focuses on written French which is building simple French sentences in the final test for French 1 (WFD10101) as a FL. Specifically, this research comparing French-BM aims to identify the similarities and differences for the French preceding preposition of location for "di" with Malay Language in writing simple French sentences.

\section{Methodology}

In line with the topic of this research, which is contrastive analysis of French and Malay Language prepositions, a document analysis study was conducted to identify the similarities and differences of the French prepositions "en", "au", "aux", "à" with the BM preposition of location "di" in simple French sentences with the verb "HABITER" which means "to live". This research was conducted, guided by the Contrastive Analysis Theory by (Lado, 1957). The research instruments were written documents that were the answer scripts for question 11, section A, in French 1 (WFD10101) test. The research sample were students of UniKL MFI. Other than that, this research also employed the questionnaire and observation methods.

\section{Research Sample}

Research population comprised of 50 technical students of UniKL MFI from various studies such as Automotive, Electrical, Welding, and Robotics. The UniKL MFI students were required to learn French as a FL in line with the status of French as a compulsory university subject and passing French is a condition to graduate. Their age range was not limited. Research sample was Malaysian students and Malay Language (BM) as their native language or B2 students. The respondents' mastery of BM was good. Respondents followed the French 1 class for 17 weeks (34 hours), before sitting for the French 1 Test. French lessons were conducted in classes equipped with air conditioning, smart board and other basic necessities, textbooks and the exercise book "Le Nouveau Taxi 1", written by (Capelle \& Menand, 2014). Paris: Hachette as well as audio CD and CD-ROM was used in the teaching and learning of French 1 and French 2 at UniKL MFI. Other than that, the instructor also prepared additional notes and the PowerPoint presentations uploaded on the UniKL online learning portal "VLE UniKL". 


\section{Research Location}

The research was conducted at a private Higher Education Institution that is University Kuala Lumpur Malaysia France Institute, located in Seksyen 14, Jalan Teras Jernang, 43650 Bandar Baru Bangi, Selangor. UniKL MFI was established in the 1980s as the result of a cooperation between UniKL MFI and the French government with the aim to generate technologists in the industry who also have a wide understanding of the French language.

\section{Research Instrument}

\section{Document Analysis}

This CA research studied the usage of preceding prepositions of place element for "di" which are "en", "au", "aux" or "à" in simple French sentences in the final French language test. The papers from the final French 1 test from January 2019 semester UniKL MFI students were chosen as research documents, after following French class for 17 weeks. Research was conducted on the answer script for question 11, section $A$, which was to write a short descriptive essay titled "Presenter quelqu'un" or to introduce someone. The respondents were required to write a short essay of 50 words based on the biodata of a female friend, which included the name, family name, age, nationality, occupation, address, father's occupation, father's nationality, mother's occupation, and mother's nationality. The focus of the research was the "address" section as it was related to the research topic, namely CA of French-BM preposition. In this section, the student will build a sentence using the verb "HABITER" which is matched with the preposition for place "en", "au", "aux" or "à" to explain someone's place of residence. Question 11 was chosen to identify the mistakes in choosing the preposition of location in French. For that reason, the research analysis for this document was conducted to identify the similarities and differences in French prepositions "en", "au", "aux" or "à" with the BM preposition of location "di". The research data was obtained by manually reviewing the written test papers. On the other hand, the raw data of the errors were collected from this test, classified according to the types of errors in choosing French prepositions "en", "au", "aux" or "à" in building a sentence after the verb "HABITER" after which the errors data were recorded using Microsoft Excel. The findings of the selection error analysis were then used to see the frequency of preposition selection error "en", "au", "aux" or "à" after the verb "HABITER" among the respondents. With the collected data, a comparative analysis on French and BM prepositions was conducted to identify the similarities and differences of French-BM prepositions. This approach supports the statement by Zaki (2015), which stated that the error analysis study and CA complement one another. Other than that, the research also utilized the questionnaire and classroom observation methods.

\section{Questionnaire}

The questionnaire method was used to examine the understanding of French grammar and background of the respondents. Each respondent was given 30 minutes to answer the questionnaire. The questionnaire was conducted in the French 1 class in UniKL MFI. A Likert scale questionnaire of a scale from 1 to 5 was among the sources used to obtain data in this research.

\section{Observation}

The researcher also observed the respondents' behaviours during the T\&L session. Additional information through the observation method was noted. The observation method was an 
additional source that helped the researcher strengthen their finding discussion for this research.

\section{Data Analysis}

After following the French classes for seventeen weeks, the UniKL MFI students for WFD10101 sat for their written test. Based on the questionnaire and the written test handed out, the data obtained were analysed to meet the objectives of the study. The review of the written test papers was manually done. The results of the manual review of the respondents' writings show that the respondents often made an error in French prepositions, especially in choosing the correct preposition from "en", "au", "aux" or "à". The French preposition of location selection error data was arranged according to the frequency of the highest to lowest incidences. Following that, the comparison of French and BM preposition of location was conducted according to the order, and it was subsequently elaborated qualitatively to reach the main objective of identifying the similarities and differences between the French preposition of location which are "en", "au", "aux" or "à" and the BM preceding preposition of place "di" after the verb "HABITER" which means "to live" in BM in written simple French sentences. The Microsoft Excel software is used to note down and process the data for the purpose of calculating the total frequency and percentage of selection errors for French preceding preposition of place which are "en", "au", "aux" or "à". As a whole, the data analysis in this research is done qualitatively.

\section{Theory}

The theory of contrastive analysis by Lado (1957) is chosen for this research. Contrastive linguistic had its beginnings in 1945. The importance of contrastive linguistics, or known as CA in teaching a foreign language, was born from the musings of Fries (1945). Next, the Fries' concept that stated the importance of applied linguistics spurred Lado (1957) to develop CA in teaching language. He also wrote on CA in his book "Linguistics A Cross Cultures; Applied Linguistics for Language Teachers" (1957). Following that, three years after his book was published, a roundtable discussion was held in relation to CA. The years 1960 and 1971 saw more roundtable discussions in Washington and Hawaii to discuss the implications of contrastive linguistics in teaching foreign languages. As a result of the discussion, contrastive linguistics was finally accepted as applied linguistics, which had its own theories and importance in teaching language. Nowadays, the importance of CA in teaching FL in Malaysia must be given attention, especially when comparing BM-French. According to Lado (1957) there are similarities and differences between B1 and B2, and the level of difficulty in the target language (TL) is divided into two: difficult or easy. Carl James defined CA as stating the opinions of Stockwell (1965) where there are two types of difficulties that students face when learning a language, namely the difficulty in building sentence structures, and difficulty in phonology. The level of difficulty is split into three, which is the relationship between B1 and B2, where firstly B1 has methods and B2 has similarities, secondly B1 has methods but B2 does not have similarities and thirdly B2 has methods but do not have any similarities with B1.

\section{Synopsis}

CA is important in research related to learning FL. The comparison of French-BM has its own advantages, and this, if conducted systematically, may provide substantial benefit to the students and teachers of French as a FL in Malaysia. The positive attitudes of the UniKL MFI 
students in being able to accept criticisms on errors in writing, understanding, or pronunciation during French class helped the WFD10101 students to master the language. However, if the students' attitudes were inverse, therefore it may make it difficult for the teachers to correct their mistakes. Nor et al (2015) stated that the differences between both languages are one of the factors that influence the learning process for FL whereby the mistakes and errors are negative elements and will disturb the students. Therefore, the differences in French-BM demand the students to possess a good learning strategy so as to not make errors when writing. Meanwhile the similarities for French-BM are a positive element that aids the students in remembering grammar well. The various forms of French preposition of location piques the researchers' interest to conduct CA studies for French-BM among the students of UniKL MFI.

\section{Results and Discussion}

Objective: comparison of French preposition of location for "di" with Malay Language in writing simple French sentences.

This research focuses on the preposition comparison for French-BM by identifying the similarities and differences of the preposition of location in French and BM in simple writing for students of French 1 (WFD10101) over 17 weeks (34 teaching hours). Therefore, the research on comparing French preposition of location which are "en", "au", "aux" or "à" is done based on the error analysis research data findings previously conducted. The main research document was the answer scripts from the French 1 final test, focusing on Section $A$ question 11, which was to write a short descriptive essay "Presenter quelqu'un" or to introduce someone in French. The respondents were required to compose a short essay of approximately 50 words based on personal information of a female friend, which includes name, family name, age, nationality, occupation, address, father's occupation, father's nationality, mother's occupation, and mother's nationality. With that, focus was given to the section on building a sentence to explain the place of residence based on the address provided. The choice of the "address" was in accordance with the title of this research, which is the comparison of French and BM preposition. Meanwhile, the error analysis research findings, is a result of the researcher manually reviewing the written paper, where it shows that there are 110 French grammatical errors in the descriptive writings of 50 respondents. These errors were noun errors (19\%), adjectives (3\%), verbs (28\%), and prepositions (50\%). The research results showed the error percentage for preposition was the highest at $50 \%$, which equated to 55 errors in choosing prepositions made by respondents in writing French. They are classified as follows:

i. Errors in choosing French preposition of location for a country

(1) Il habite au Italie

(2) Elle habite en Canada

(3) Il habite à Italie.

(4) Elle habite à Canada

There were errors in choosing prepositions to show place for a country in sentences (1), (2), (3), and (4) which are prepositions "au", "en" and "à". In French, there are 3 types of prepositions for a country. This preposition is determined by the gender of the country and is written before the name of the country that brings the meaning of "di" in BM. The preposition for a feminine state is "en", while for a masculine state is "au", and for plural masculine it is 
"aux". The error in sentence (1) was the error in choosing the "au" preposition for a feminine state such as Italie. The correct answer should be "Il habite en Italie". For sentence (2), the respondent wrongly chose the preposition "en" before a masculine state that is Canada. The respondent should have selected the preceding preposition "au" for Canada, which would read as "Elle habite au Canada". Other than that, there was a third error in choosing the preposition for sentences (3) and (4), which was the error in choosing the preposition "à" for a country. The correct answer for sentence (3) is "Il habite en Italie" and "Elle habite au Canada" for sentence (4).

ii. Error in choosing a preposition of location for a city

(5) II habite en Naples

(6) II vit dans Naples

The respondent wrongly chose the preposition for sentences (5) and (6), as Naples is a city and not a country. Therefore, the preposition of location for a city in French is "à" and not as in sentences (5) and (6) as the error was in writing the preposition "en" and "dans" before a city. The sentence structure with the correct preposition in French to explain about the place which is "di" before a city is "Il habite à Naples".

iii. A reduction error by not putting a preposition of location for a country as well as city

(7) Elle habite Toronto

(8) Il habite __ Naples

(9) II habite __ Italie (f)

(10) Elle habite __ Canada $(m)$

The errors in sentences (7), (8), (9) and (10) were not in putting the preposition "en" for a feminine country, "au" for a masculine country, and "à" before the name of the city. The preposition for sentence (7) should read "Elle habite à Toronto" and sentence (8) "Il habite à Naples". As for sentence (9) it should be "Il habite en Italie" as Italie is a feminine country and sentence (10) should be "Elle habite au Canada", with the preposition "au" chosen as Canada is a masculine country.

iv. Error in leaving out the accent grave on the preposition "à" before the name of a city

(11) Elle habite a Toronto au Canada

(12) II habite a Naples en Italie

A number of respondents took the easy way out when writing the preposition "à" before a place such as cities, villages, as well as islands. In French, the accent above "a" is an "accent grave" and plays an important role in differentiating the differences between a preposition and a verb. In this case, "à" with the upper accent brings the meaning of "di" in BM and acts as a French preposition of location for cities, villages, and islands. On the other hand, an "a" written with the "accent grave" or upper accent brings a different meaning. This change can bring about a substantial change in meaning as "a" without the "accent grave" brings a different meaning as it comes from the verb "AVOIR" with is conjugated with the third person singular pronoun "Il a..." or "Elle a..." which means "She/He has...". From this, it is clear to see the importance of adding the accent above the "à" or the "accent grave" as the meaning will change as will the function whereby it is the difference between the preposition "di" and the 
verb "AVOIR". The correct sentence for (11) and (12) are "Elle habite à Toronto au Canada" and "Il habite à Naples en Italie"

v. Addition error

(13) Il est de en Naples, Italie

(14) II habite en ville Naples en pays Italie

Respondents performed additional error in sentence (13), where they added another preposition, which is "en" after the preposition "de" which means "dari" in BM. The structure for sentence (13) would be correct if the second preposition of "en" was dropped. The correct sentence would read as "Il est de Naples, Italie". As for sentence (14), the first error was in choosing the preposition "en" before the city name noun, followed by a second error which is the addition of the noun "ville" (city), and the third error is the adding of the noun "pays" before the country "Italie". Without the addition of the noun "ville" and "pays", the correct sentence structure is as follows after the preposition "en" before the Naples is dropped and replaced with the preposition "à", "Il habite à Naples en Italie".

Differences between the two languages were among the factors that influenced the learning process for French as a FL. Throughout the learning process, the student would often make mistakes and errors especially when forming French prepositions of location which are "en", "au", "aux" or "à" as these French prepositions are related to the gender and number aspect when producing a correct sentence. Errors in choosing will interfere with the student when learning French and it must be avoided. Therefore, these multiple prepositions caused researchers to be interested to conduct studies related to the contrastive analysis between French and BM. With that reasoning, the objective of this research was to compare the French preceding preposition of location "di" with BM in writing simple French sentences and subsequently to identify the similarities and differences in forming prepositions for both languages.

The choosing of the French preposition of location "en", "au", "aux" or "à" is based on the gender and number of the chosen place nouns to produce correct sentences. This is in contrast with the BM preceding preposition of place "di" which does not require the gender and number aspect, only the preposition "di" is used to country, "Saya tinggal di..." as the place noun and country does not have a gender in BM. However, in French, there are 4 choices for prepositions which are "en", "au", "aux" or "à" and it all brings the same meaning of "di" even though it is spelled differently. There are several criteria that need to be accounted for when choosing a preposition of place. Although the choosing of the preposition is based on the gender and number of the chosen place noun, however there is one exception for the preposition "à". The preposition "à" holds similarities to the BM preposition "di" which means "di" when written before a place name such as a special name for cities, villages, as well as islands as the usage of the preposition "à" is not based on gender and number, for example "J'habite à Putrajaya.", "Il habite à Serdang" and "Elle habite à Langkawi".

However, the prepositions "en", "au", "aux" differs in usage if the place noun is a country or even a continent. The respondents need to be aware of the gender and number factor for a country whereby the countries in this world are assigned their own gender in French whether it is masculine, feminine, or plural. In this matter, the preposition "en" is written before a 
feminine country, for example "Malaisie" and "France", the preposition "au" is used for masculine countries such as "Portugal" and "Japon", while the preposition "aux" is used for plural countries such as "Etats-Unis" and "Philippines". Other than this gender factor, there is also an additional difference when using the preposition "en" or "au" in French. The first difference is in choosing the preposition "en" whereby the criterion is to not follow the gender and number but to follow the first letter of the name of the country. If the spelling of the country begins with the vocals "a", "e", "i", "o", "u" as well as a silent " $h$ ", therefore the preposition "en" is the correct match for the country, for example "en Angleterre", "en Italie" and "en Espagne". The second difference is the usage of the preceding preposition for continental nouns. The preposition for every continent in the world in French is "en", for example "en Asie", "en Afrique" and "en Europe". However, the third difference is that there is an exception in using the preposition "au" preceding countries such as "Mexique", "Cambodge" and "Mozambique". An explanation should be given to the respondents during lessons that there is a spelling exception for several countries that end with the letter " $\mathrm{e}$ ". Majority of the respondents made a generalization that the spelling for the feminine noun ends with " $\mathrm{e}$ ", for example "Belgique", "Suisse" and "Indonésie". However, there are some exceptions for several countries ending with " $e$ " and these countries' genders are masculine even though they end with "e" for example "Mexique", "Cambodge" and "Mozambique", as this criterion often confuses the respondents. The similarities of preposition of location help students to build their sentences correctly, while the differences confuse the respondents in making the correct preposition choice especially when the respondents fail to understand the concept of French gender and number. Other than that, this research also helps educators and teaching staff of the French language to understand the problems faced by students during the learning process of French language, and the choosing of the preposition of location when writing as stated by Zaki (2015) CA aids educators in identifying the root cause of the problem and in searching for an approach to correct the mistakes of the B2 students. The CA research conducted is also vital in the teaching and learning process of foreign languages as well as eases the process of translating and understanding among students.

\section{Conclusion}

As a whole, the various forms of French preposition of location "di", namely "en", "au", "aux" or "à" was the main reason why respondents made errors in choosing French prepositions. The findings of this CA research showed that respondents need to understand the concept of French gender and number if they intend to master the French language. The similar attributes of French-BM prepositions helped respondents to build sentences, while the differences confused them when choosing the correct preposition as stated by Nor et al (2015) in their research. There are various differences of the French preposition for "di" which are "en", "au" or "aux". These prepositions are differentiated by the gender and number, whether the country is feminine, masculine, or plural. Meanwhile, there is one similarity of French preposition of location when compared to the Malay Language which is the preposition "à" and the preposition "di". This preposition is not determined by the gender or number factor. This preposition is written preceding the name of the place such as cities, villages, and islands. Although there are similar elements, there were still some respondents who made the error in choosing between the prepositions "en", "au", "aux" or "à". The respondents took the prepositions lightly, when in fact they need to master the gender of the countries in the world as French prepositions are written according to the country's gender. As for cities, villages, or islands, the usage of prepositions is different from countries. This 
matter causes confusion in choosing the correct prepositions among the students who learn French as a FL. Therefore, the problems of these B1 and B2 mix-up were also influenced as they wrongly chose between the "en", "au", "aux" or "à" prepositions when writing French. As stated by James (1980) the problems of language disruption may cause something easy to be difficult and that this problem can be overcome with the CA approach.

In conclusion, through this comparative research for French-BM preposition of location that was conducted, it is hoped that it may be beneficial to students studying French as a FL and it can aid the students to understand the concept of the diversity in the preposition of location which is influenced by the gender and number aspect whether it is singular or plural. Next, through this CA, it is also hoped that students are able to correctly choose between the "en", "au", "aux" or "à" prepositions when matched with the verb "HABITER" and place nouns, countries, or islands which means "to live" and followed by the preposition "di" for the location of place in BM. Good writing is dependent on the mastery of French grammar, understanding the concept of gender and French vocabulary. The problem of errors in learning a $\mathrm{FL}$ is an important element to measure the level of understanding and attainment of the target language. Other than that, the findings of the comparative analysis on preposition of location "en", "au", "aux" or "à" in French and "di" in BM may benefit the teaching staff as well as students learning French as a FL in Malaysia. The educators may plan effective teaching and learning strategies in order to aid the French language students to handle problems relating to the confusion in choosing the correct French preposition of location and subsequently being able to write and master the French language.

\section{Acknowledgement}

From the bottom of my heart, I would like to take this opportunity to express my appreciation and thanks to UniKL, UPM, UniKL MFI, Pre-France Section, French Unit, all lecturers, colleagues and family for all the support and encouragement during this research. Not also forgetting my infinite appreciation and thanks to all my French 1 students for their participation in this CA research.

\section{Corresponding Author}

Shobehah binti Abdul Karim University Kuala Lumpur Malaysia France Institute, Malaysia Section 15, Jalan Teras Jernang, 43650 Bandar Baru Bangi, Selangor Darul Ehsan.

Email: shobehah@unikl.edu.my 


\section{References}

\section{Journal Article}

Che Su, N. (2017). Analisis Kontrastif Kata Sendi Nama 'Pada' Bahasa Melayu dan Bahasa Thai. Jurnal Linguistik, 21 (1), 55-66.

Nor, M. H., Hamzah, Z. A., Husain, S., \& Che Su, N. (2015). Contrastive Analysis of Adjectives Formation of Malay and Spanish. EDUCATUM Journal of Social Sciences, 1(1), 1-13.

Hassan, O., \& Mohamad, A. H. (2014). Perbandingan Kata Kerja Sokong dalam Malay Language dan Bahasa Perancis (Comparison of Support Verbs in Malay and French). Kemanusiaan, 21(1), 21-40.

Nur, T. (2016). Analisis Kontrastif Dalam Studi Bahasa. Jurnal Arabi: Journal of Arabic Studies, 1(2), 64-74.

Baihaqi, H. M., \& Aminallah, F. H. (2017). Contrastive Analysis of Gender (المذكر والمؤنث ) In the Use of Arabic and Malay Language Among Engineering Students of Universiti Malaysia Pahang. Journal Of Global Business and Social Entrepreneurship (GBSE), 1 (1), 100-109.

Al-khresheh, M. H. (2016). A review study of contrastive analysis theory. Journal of advances in humanities and social sciences, 2(6), 330-338.

\section{Book}

Zaki, M. T. (2015). Contrastive linguistics: Approaches and Methods: Cairo University James, C. (1980). Contrastive Analysis. London: Longman.

Lado, R. (1957). Linguistics across cultures. Ann Arbor, Michigan: University of Michigan Press.

\section{Thesis}

Halim, A. H. (2011). Pengaruh Malay Language Dalam Strategi Komunikasi Penulisan Bahasa Perancis. Unpublished Ph.D. thesis. Universiti Putra Malaysia, Serdang, Malaysia.

Nor, M. M. H. (2015). Perbandingan Bentuk Kata Adjektif Bahasa Sepanyol Dengan Malay Language Dalam Penulisan Pelajar IPTA. Unpublished Ph.D. thesis. Universiti Putra Malaysia, Serdang, Malaysia. 